\title{
Genetic Diversity and Expression of the [NiFe] Hydrogenase Large-Subunit Gene of Desulfovibrio spp. in Environmental Samples
}

\author{
CATHRIN WAWER, ${ }^{1}$ MIKE S. M. JETTEN,${ }^{2}$ AND GERARD MUYZER ${ }^{1 *}$ \\ Molecular Ecology Group, Max-Planck-Institute for Marine Microbiology, D-28359 Bremen, Germany, ${ }^{1}$ \\ and Kluyver Laboratory for Biotechnology, Delft University of Technology, \\ NL-2628 BC Delft, The Netherlands ${ }^{2}$
}

Received 14 July 1997/Accepted 26 August 1997

\begin{abstract}
The genetic diversity and expression of the [NiFe] hydrogenase large-subunit gene of Desulfovibrio spp. in environmental samples were determined in order to show in parallel the existing and active members of Desulfovibrio populations. DNA and total RNA were extracted from different anaerobic bioreactor samples; RNA was transcribed into cDNA. Subsequently, PCR was performed to amplify a ca.-440-bp fragment of the [NiFe] hydrogenase large-subunit gene and its mRNA. Denaturing gradient gel electrophoresis analysis was used to separate the PCR products according to their sequence and thereby to visualize the individual community members. Desulfovibrio strains corresponding to amplified [NiFe] hydrogenase transcripts were regarded as metabolically active, because in pure cultures transcripts were detectable in exponentially growing cells but not in cultures in the stationary phase. DNA sequencing and comparative sequence analysis were used to identify the detected organisms on the basis of their [ $\mathrm{NiFe}$ ] hydrogenase sequences. The genes of characterized Desulfovibrio spp. showed a considerable extent of divergence (ca. 30\%), whereas sequences obtained from bacterial populations of the bioreactors showed a low level of variation and indicated the coexistence of closely related strains probably belonging to the species Desulfovibrio sulfodismutans. Under methanogenic conditions, all detected populations were active; under denitrifying conditions, no [NiFe] hydrogenase mRNA was visible. Changes in activity and composition of Desulfovibrio populations caused by changes in the environmental conditions could be monitored by using the approach described in this study.
\end{abstract}

Diversity and metabolic activity of organisms play an important role in ecological studies of microbial communities. Molecular techniques can be used to analyze composition and genetic diversity without the need for cultivation of individual species $(1,29)$. Targeting DNA and the detection and analysis of specific genes can reveal the existing microbes within an environmental sample, including both dormant and inactive organisms. Identification of the organisms by comparative sequence analysis can lead to conclusions about their potential activity but not about the actual in situ activity. Thus, rRNA sequences are now being employed more frequently to study microbial communities. Because of the higher number of ribosomes in metabolically active cells than in dormant cells, it is assumed that analysis of rRNA instead of genomic DNA reflects the metabolically active organisms $(12,40,48)$. A more specific approach to monitor microbial activity and to understand the function of the community members, however, is the analysis of mRNA. Detection of mRNA can ensure that the target gene, and therefore the corresponding microorganism, is active.

There exist probes and specific PCR assays for functional genes of a variety of bacterial groups, such as the gene encoding formyltetrahydrofolate synthase in acetogenic bacteria (25), nifD and nifH in $\mathrm{N}_{2}$-fixing bacteria $(49,62)$, the dissimilatory nitrite reductase genes in denitrifying bacteria (55), the ammonium mono-oxygenase gene in ammonium-oxidizing bacteria (45), the methane mono-oxygenase gene in methano-

\footnotetext{
* Corresponding author. Mailing address: Molecular Ecology Group, Max-Planck-Institute for Marine Microbiology, Celsiusstr. 1, D-28359 Bremen, Germany. Phone: 49-421-2028-934. Fax: 49-4212028-690. E-mail: gmuyzer@mpi-bremen.de.
}

trophs (27), and the hydrogenase genes in aerobic $\mathrm{H}_{2}$-oxidizing bacteria (19) and sulfate-reducing bacteria $(54,56)$. Nevertheless, the detection of mRNA in natural populations has been demonstrated for only a few genes. These include, for instance, the ribulose-1,5-bisphosphate carboxylase large-subunit gene $(r b c L)$ in phytoplankton populations $(35,39,61)$, genes responsible for the detoxification of mercurial compounds from a microbial community of a mercury-contaminated pond (16), and the nifH gene in natural populations of an $\mathrm{N}_{2}$-fixing marine cyanobacterium (60).

We are interested in the ecological role of sulfate-reducing bacteria. Sulfate-reducing bacteria occur in a variety of anaerobic habitats, where they are involved in the terminal degradation of organic matter, the sulfur cycle, and the anaerobic corrosion of metals (57). Recently, we developed a PCR-based detection system which specifically amplifies [NiFe] hydrogenase large-subunit gene sequences of the sulfate-reducing genus Desulfovibrio (56). Furthermore, it allows the discrimination of different strains by denaturing gradient gel electrophoresis (DGGE) of amplified gene fragments. The main objective of this study was to extend this assay to the analysis of mRNA. The [NiFe] hydrogenase plays an important role in the energy metabolism of Desulfovibrio spp. (14). Therefore, its expression should be an excellent marker for the metabolic activity of those bacteria in the environment.

Here, we describe a molecular approach that attempts to differentiate the active from the dormant members within populations of Desulfovibrio spp. in environmental samples.

\section{MATERIALS AND METHODS}

Cultivation of bacteria. Strains of Desulfovibrio spp. were obtained from the Deutsche Sammlung von Mikroorganismen und Zellkulturen (Braunschweig, 
Germany). Strain PIB2 ("Desulfovibrio oxyclinae" [21]) was isolated from the microbial mat of Solar Lake (Sinai, Egypt) by Yehuda Cohen (The Moshe Shilo Center for Marine Biogeochemistry, Jerusalem, Israel).

The bacteria were grown anaerobically in a defined, bicarbonate-buffered, sulfide-reduced medium at $28^{\circ} \mathrm{C}(58)$. The electron donor was in most cases 20 $\mathrm{mM}$ lactate. Cultivation with hydrogen was performed with $2 \mathrm{mM}$ acetate as carbon source under an atmosphere of $\mathrm{H}_{2}-\mathrm{CO}_{2}$ (80:20 [vol/vol]).

Growth experiments. Different strains of Desulfovibrio spp. were grown as batch cultures in a lactate-sulfate medium. A large volume of medium was inoculated with a fresh culture (1 to $5 \%$ [ $\mathrm{vol} / \mathrm{vol}])$ and divided into $10-$ or $50-\mathrm{ml}$ portions to facilitate sampling. Growth was measured by monitoring the optical density of the cultures at $660 \mathrm{~nm}$. Sulfide was determined colorimetrically by the methylene blue method (5) with a final reaction volume of $4 \mathrm{ml}$ containing 2 to $20 \mu \mathrm{l}$ of a culture.

Isolation of RNA from bacterial cultures. RNA was isolated from bacterial cultures by the method of Oelmüller et al. (32). Cells of 10- to 50-ml cultures were harvested, washed in $1 \mathrm{ml}$ of SSC $(150 \mathrm{mM} \mathrm{NaCl}, 15 \mathrm{mM}$ sodium citrate $[\mathrm{pH} 7])$, and resuspended in $500 \mu \mathrm{l}$ of ice-cold AE buffer $(20 \mathrm{mM}$ sodium acetate [pH 5.5], $1 \mathrm{mM}$ EDTA). The solution was incubated with $1 \mathrm{ml}$ of hot phenolchloroform-isoamyl alcohol $(25: 24: 1)$ and $10 \mu \mathrm{l}$ of $25 \%(\mathrm{wt} / \mathrm{vol})$ sodium dodecyl sulfate (SDS) for $10 \mathrm{~min}$ at $60^{\circ} \mathrm{C}$, cooled on ice, and centrifuged at $4^{\circ} \mathrm{C}$. The aqueous phase was mixed with $62.5 \mu \mathrm{l}$ of $2 \mathrm{M}$ sodium acetate (pH 5.5) and $1 \mathrm{ml}$ of phenol-chloroform-isoamyl alcohol for $5 \mathrm{~min}$. The aqueous phase was again extracted with $1 \mathrm{ml}$ of phenol-chloroform-isoamyl alcohol. After ethanol precipitation, the pellet was dissolved in $100 \mu \mathrm{l}$ of DNase buffer $(40 \mathrm{mM}$ Tris- $\mathrm{HCl}$ [pH 7.5], $6 \mathrm{mM} \mathrm{MgCl}_{2}, 2 \mathrm{mM} \mathrm{CaCl}$ ) and incubated with 10 to $40 \mathrm{U}$ of RNase-free DNase (Boehringer) for $30 \mathrm{~min}$ at $37^{\circ} \mathrm{C}$. The enzyme was removed by phenolchloroform extraction followed by ethanol precipitation. The resulting RNA pellet was dissolved in 20 to $40 \mu \mathrm{l}$ of water.

Western blotting and immunodetection of hydrogenase subunits. Cell lysates were prepared by direct lysis of bacteria in a modified sample solution for SDS-polyacrylamide gel electrophoresis $(2 \%$ [wt/vol] SDS, $10 \%$ [vol/vol] glycerol, $100 \mathrm{mM}$ Tris- $\mathrm{HCl}$ [pH 6.8], 0.4\% [vol/vol] 2-mercaptoethanol). The protein content was determined by the method of Bradford (3) with bovine serum albumin used as a standard. Cell lysates were electrophoresed in 15\% (wt/vol) polyacrylamide gels containing $0.2 \%$ (wt/vol) SDS (23). Proteins were transferred from the gels to hydrophobic Immobilon membranes (Millipore) for $1 \mathrm{~h}$ at $200 \mathrm{~mA}$ with a Trans-Blot SD Semi Dry Transfer Cell (Bio-Rad Laboratories, Inc.). The membranes were washed with Tris-buffered saline (TBS) (Tris-HCl $[\mathrm{pH} 7.4], \mathrm{NaCl}, \mathrm{KCl}$ ), treated with $10 \%$ (vol/vol) horse serum in TBS- $0.05 \%$ ( $\mathrm{vol} / \mathrm{vol})$ Tween 20 for at least $1 \mathrm{~h}$, and incubated with antiserum raised against the [NiFe] hydrogenase of D. gigas (E. C. Hatchikian, Centre National de la Recherche Scientifique, Marseille, France) diluted 1:1,000 in TBS-1\% (vol/vol) horse serum- $0.05 \%$ (vol/vol) Tween 20 for $1 \mathrm{~h}$. Unbound antibodies were removed by five 10 -min washes with TBS- $0.05 \%$ (vol/vol) Tween 20 . Immunodetection of bound antibodies was done by using anti-rabbit immunoglobulin $\mathrm{G}$ conjugated to alkaline phosphatase (Sigma no. A3687), diluted 1:30,000, and a subsequent color reaction with 5-bromo-4-chloro-3-indolyl phosphate and nitroblue tetrazolium salt.

Bioreactor samples. Samples were obtained from two experimental bioreactors (Delft University of Technology, Delft, The Netherlands). The methanogenic bioreactor was fed with wastewater from a baker's yeast production plant and originally inoculated with methanogenic sludge from the wastewater plant of a Dutch sugar factory. The denitrifying fluidized bed reactor (28) has been in operation for 5 years and was originally inoculated with denitrifying sludge from a municipal wastewater treatment plant. The denitrifying bioreactor was fed with the effluent from the methanogenic bioreactor. Sludge samples from the bioreactors were either immediately frozen in liquid nitrogen for subsequent nucleic acid extraction or used for incubation with different substrates.

Biomass (25 to $50 \%$ [vol/vol]) from the denitrifying bioreactor was incubated with $\mathrm{KHCO}_{3}$-buffered media (50). The headspace of the vials was changed with $\operatorname{argon}-\mathrm{CO}_{2}(95: 5[\mathrm{vol} / \mathrm{vol}])$ or $\mathrm{H}_{2}-\mathrm{CO}_{2}(90: 10[\mathrm{vol} / \mathrm{vol}])$. For aerobic incubation, the vials were sparged with air. After $20 \mathrm{~h}$ at $28^{\circ} \mathrm{C}$, the biomass was harvested and immediately frozen in liquid nitrogen.

Enrichments of sulfate-reducing bacteria from the methanogenic bioreactor were started with $5 \%$ (vol/vol) sludge in $50 \mathrm{ml}$ of defined, bicarbonate-buffered, sulfide-reduced freshwater medium (58) with $20 \mathrm{mM}$ lactate or hydrogen-2 mM acetate. A sulfide test with $\mathrm{Cu}^{2+}$ ions yielding $\mathrm{CuS}$ was applied (6) to confirm the activity of sulfate-reducing bacteria. After 1 day of incubation at $28^{\circ} \mathrm{C}$, the biomass from the starting enrichment cultures and cultures after the first transfer in fresh medium was harvested and frozen in liquid nitrogen.

Nucleic acid extraction from bioreactor samples. Nucleic acids were recovered directly from the bioreactor samples by the method described above, which was adapted as follows. Ca. $10 \mathrm{~g}$ (wet weight) of frozen sludge was mixed with $8 \mathrm{ml}$ of AE buffer, $20 \mathrm{ml}$ of hot phenol-chloroform-isoamyl alcohol (25:24:1), and 200 $\mu \mathrm{l}$ of $25 \%$ (wt/vol) SDS, shaken for $30 \mathrm{~min}$ at $60^{\circ} \mathrm{C}$, and cooled on ice. After centrifugation, $2 \mathrm{M}$ sodium acetate ( $\mathrm{pH}$ 5.5) was added to a final concentration of $0.25 \mathrm{M}$ to the aqueous phase, which was repeatedly extracted with 1 volume of phenol-chloroform-isoamyl alcohol $(25: 24: 1)$ until no protein precipitate was observed at the aqueous-organic interface. Nucleic acids were precipitated with ethanol and either treated with DNase-free RNase or with RNase-free DNase (Boehringer) to obtain DNA and RNA, respectively.
The quality of the nucleic acid preparations was tested in $2 \%(\mathrm{wt} / \mathrm{vol})$ agarose gels with MOPS (morpholinepropanesulfonic acid) buffer; their concentration and purity were determined by absorption spectrophotometry (43).

RT of RNA. Prior to PCR amplification, total RNA preparations were transcribed into cDNA in a final volume of $20 \mu \mathrm{l}$ as follows. A $0.5-$ to $1-\mu \mathrm{g}$ sample of RNA and 10 pmol of hexanucleotides (Boehringer) were denatured for $10 \mathrm{~min}$ at $70^{\circ} \mathrm{C}$ and immediately placed on ice. Subsequently, $4 \mu \mathrm{l}$ of deoxynucleoside triphosphates $(2.5 \mathrm{mM}$ each) and $4 \mu \mathrm{l}$ of $5 \times$ reverse transcription (RT) buffer (250 mM Tris- $\mathrm{HCl}$ [pH 8.3], $375 \mathrm{mM} \mathrm{KCl}, 15 \mathrm{mM} \mathrm{MgCl}_{2}, 50 \mathrm{mM}$ dithiothreitol) were added. The RT mix was incubated for $2 \mathrm{~min}$ at $37^{\circ} \mathrm{C}$ before $1 \mu \mathrm{l}$ of Moloney murine leukemia virus $\mathrm{H}^{-}$reverse transcriptase $(200 \mathrm{U} / \mu \mathrm{l}$; Promega) was added. After incubation for $1 \mathrm{~h}$ at $37^{\circ} \mathrm{C}$, the samples were heated to $95^{\circ} \mathrm{C}$ for $5 \mathrm{~min}$ and immediately cooled on ice to stop the reaction.

PCR amplification. Primers complementary to conserved regions in the [NiFe] hydrogenase large-subunit gene of Desulfovibrio spp. were used to amplify a ca.-440-bp DNA fragment (56) corresponding to positions 1441 to 1879 in the $D$. vulgaris sequence (8). The nucleotide sequence of the forward primer Hyd1F (5'-CGCGACGCCCAGCACTTCACCCAGCGC- $3^{\prime}$ ) contained at its $5^{\prime}$ end a 40-base GC clamp (5'-CGCCCGCCGCGCCCCGCGCCCGTCCCGCCGCCC CCGCCCG-3') to stabilize the melting behavior of the DNA fragments in denaturing gradient gels (56). The sequence Hyd5R (5'-GCAGGGCTTCCAG GTAGTGGGCGGTGGCGATGAGGT-3') was used as the reverse primer. PCR amplifications were performed in a final volume of $50 \mu \mathrm{l}$ containing 0.1 to $1 \mu \mathrm{g}$ of DNA or $5 \mu \mathrm{l}$ of the RT mix, $25 \mathrm{pmol}$ of each primer, $200 \mu \mathrm{M}$ each deoxyribonucleoside triphosphate, $5 \mu$ l of $10 \times$ PCR buffer $(100 \mathrm{mM}$ Tris- $\mathrm{HCl}$ [pH 9], $15 \mathrm{mM} \mathrm{MgCl}_{2}, 500 \mathrm{mM} \mathrm{KCl}, 0.1 \%$ [wt/vol] gelatin, $1 \%$ [vol/vol] Triton $\mathrm{X}-100$ ), and $0.5 \mathrm{U}$ of SuperTaq DNA polymerase (HT Biotechnology, Ltd.) as previously described (56). The amplification products were analyzed by electrophoresis in $2 \%(\mathrm{wt} / \mathrm{vol})$ agarose gels.

Confirmation that PCR products obtained after amplification of the RT mix were derived from mRNA and not from contaminating DNA within the RNA preparation-negative controls was done as follows: either 0.5 to $1 \mu \mathrm{g}$ of total RNA or $5 \mu$ l of the RT mix without reverse transcriptase added was used for PCR.

DGGE analysis. PCR samples were separated in $6 \%(\mathrm{wt} / \mathrm{vol})$ polyacrylamide gels with gradients ranging from 30 to $70 \%$ denaturants at a constant voltage of $200 \mathrm{~V}$ and a temperature of $60^{\circ} \mathrm{C}$ for $4 \mathrm{~h}$ by use of a Bio-Rad Protean II system as described previously (56).

Determination of nucleotide sequences. PCR products of pure bacterial cultures were obtained by amplification of genomic DNA isolated as previously described (56) using primers Hyd1F without the GC clamp and Hyd5R. Selected DGGE bands were punched from the gel. The DNA was eluted as described elsewhere (30) and reamplified with primer pair Hyd1F-Hyd5R. Prior to sequencing, the PCR products were purified with a Quiaquick Spin PCR purification kit (Quiagen Inc.). The DNA fragments were directly sequenced with primer Hyd1F and a truncated form of Hyd5R (Hyd5-18, 5'-GCAGGGCTTCCAGGT AGT-3') by using the Taq Dye Deoxy Terminator Cycle Sequencing kit and the DNA sequencer 373 S of Applied Biosystems (Foster City, Calif.) in accordance with the manufacturer's directions.

Sequence analysis. The deduced amino acid sequences were obtained from the nucleotide sequence data by using the software program DNA Strider 1.2 (26) and aligned with each other manually by using the editor SeqApp (13). The alignment was improved by using the Genetics Computer Group analysis software package (Biotechnology Center, University of Wisconsin, Madison). The nucleotide sequences were aligned according to the alignment of the deduced amino acid sequences. A distance matrix from the aligned sequences was obtained by using the "show distance matrix" option in the software program PAUP 3.1 (47).

In estimates of evolutionary relationships, regions with missing data were omitted from the alignment. Matrices of evolutionary distances were computed by using DNADIST (Kimura option) for nucleotide sequences and PROTDIST (Dayhoff PAM option) for amino acid sequences. Evolutionary trees were constructed from these evolutionary distances with the program FITCH. All programs are implemented in the software package PHYLIP 3.5 (11). The reliability of tree nodes was determined by bootstrap analysis (100 replicates) using SEQ BOOT implemented in PHYLIP 3.5 (11) and PAUP 3.1 (47).

Nucleotide sequence accession numbers. The sequences determined in this study are available from GenBank under accession no. AF012053 to AF012068.

\section{RESULTS}

Expression of the [NiFe] hydrogenase gene in pure cultures. [NiFe] hydrogenase mRNA was detected by RT-PCR in exponentially growing cells of various Desulfovibrio spp. with lactate or hydrogen as an electron donor in the presence of sulfate (Table 1). However, D. desulfuricans DSM 1926 did not grow with hydrogen as an energy source, as was also demonstrated by Devereux et al. (9). Thus, mRNA was not analyzed.

In addition, $D$. vulgaris DSM 644, D. desulfuricans DSM 
TABLE 1. Expression of the $[\mathrm{NiFe}]$ hydrogenase gene in Desulfovibrio spp. under different growth conditions

\begin{tabular}{lcc}
\hline \multicolumn{1}{c}{ Strain } & \multicolumn{2}{c}{$\begin{array}{c}\text { Result with the indicated } \\
\text { electron donor }\end{array}$} \\
\cline { 2 - 3 } & $20 \mathrm{mM}$ lactate & $\mathrm{H}_{2}$ \\
\hline D. baculatus DSM 2555 & + & + \\
D. gigas DSM 1382 & + & + \\
D. desulfuricans & & $\mathrm{ND}$ \\
DSM 1924 & + & - \\
DSM 1926 & + & + \\
D. vulgaris & & + \\
DSM 644 & + & + \\
DSM 1744 & + & + \\
\hline
\end{tabular}

${ }^{a}+$, PCR products after RT-PCR; ND, not determined; -, no growth.

1926, and D. baculatus DSM 2555 were grown in lactate-sulfate medium. Growth, sulfide production, and the expression of the [NiFe] hydrogenase gene were monitored until the cultures reached the stationary phase. Figure 1 shows the results obtained with $D$. baculatus, which are representative for all tested strains. The cultures reached the stationary phase $35 \mathrm{~h}$ after inoculation (Fig. 1A). [NiFe] hydrogenase mRNA was detectable in exponentially growing cells at 5 to $30 \mathrm{~h}$ after inoculation, as determined by RT-PCR amplification of a ca. $-440-b p$ fragment from equal amounts of total RNA and subsequent agarose gel electrophoresis. As the culture approached the stationary phase, the mRNA level decreased, and mRNA was no longer visible after $45 \mathrm{~h}$ (Fig. 1B). The large and the small subunits of the $[\mathrm{NiFe}]$ hydrogenase were detected by Western immunoblotting. Antisera raised against the $[\mathrm{NiFe}]$ hydrogenase of $D$. gigas (31) cross-reacted with proteins of the correct size for the large $(60-\mathrm{kDa})$ and the small $(30-\mathrm{kDa})$ subunits. In contrast to the RT-PCR-amplified mRNA, no difference in the intensity of stained proteins was observed, indicating that the amount of $[\mathrm{NiFe}]$ hydrogenase relative to the total protein content of the cultures did not change during growth over $55 \mathrm{~h}$.

Detection of [NiFe] hydrogenase gene fragments and mRNA in anaerobic bioreactors. The presence and expression of the [NiFe] hydrogenase gene of Desulfovibrio spp. were investigated in a denitrifying and a methanogenic bioreactor. In parallel, DNA and RNA were isolated and used as templates for PCR and RT-PCR, respectively. The PCR products were analyzed by DGGE to visualize the individual members of the Desulfovibrio populations. As previously demonstrated (56), DGGE analysis of amplified [NiFe] hydrogenase gene fragments allows the discrimination of different Desulfovibrio strains due to the different migration behavior caused by sequence variations within their PCR products.

The gel electrophoresis analysis of PCR products obtained from samples of the denitrifying bioreactor is shown in Fig. 2. [NiFe] hydrogenase gene fragments were amplified from DNA isolated from a sample taken directly out of the reactor. Positive results were also found for DNA obtained from subsamples that were incubated with hydrogen and oxygen to induce and inhibit gene expression, respectively. The corresponding mRNA was detectable in only the bioreactor subsample which was incubated with hydrogen. Agarose gel electrophoresis of the PCR products revealed that the sizes of all amplified fragments were as expected for the [NiFe] hydrogenase of Desulfovibrio spp. (Fig. 2A). DGGE analysis (Fig. 2B) of the amplified gene fragments showed several bands with identical electrophoresis patterns. Only one band in the denaturing gradient gel was observed for the PCR products derived from mRNA. This band showed the same position in the gel as a band in the DGGE pattern derived from amplified DNA.

Samples from the methanogenic bioreactor were analyzed as described above. Enrichment cultures of sulfate-reducing bac-
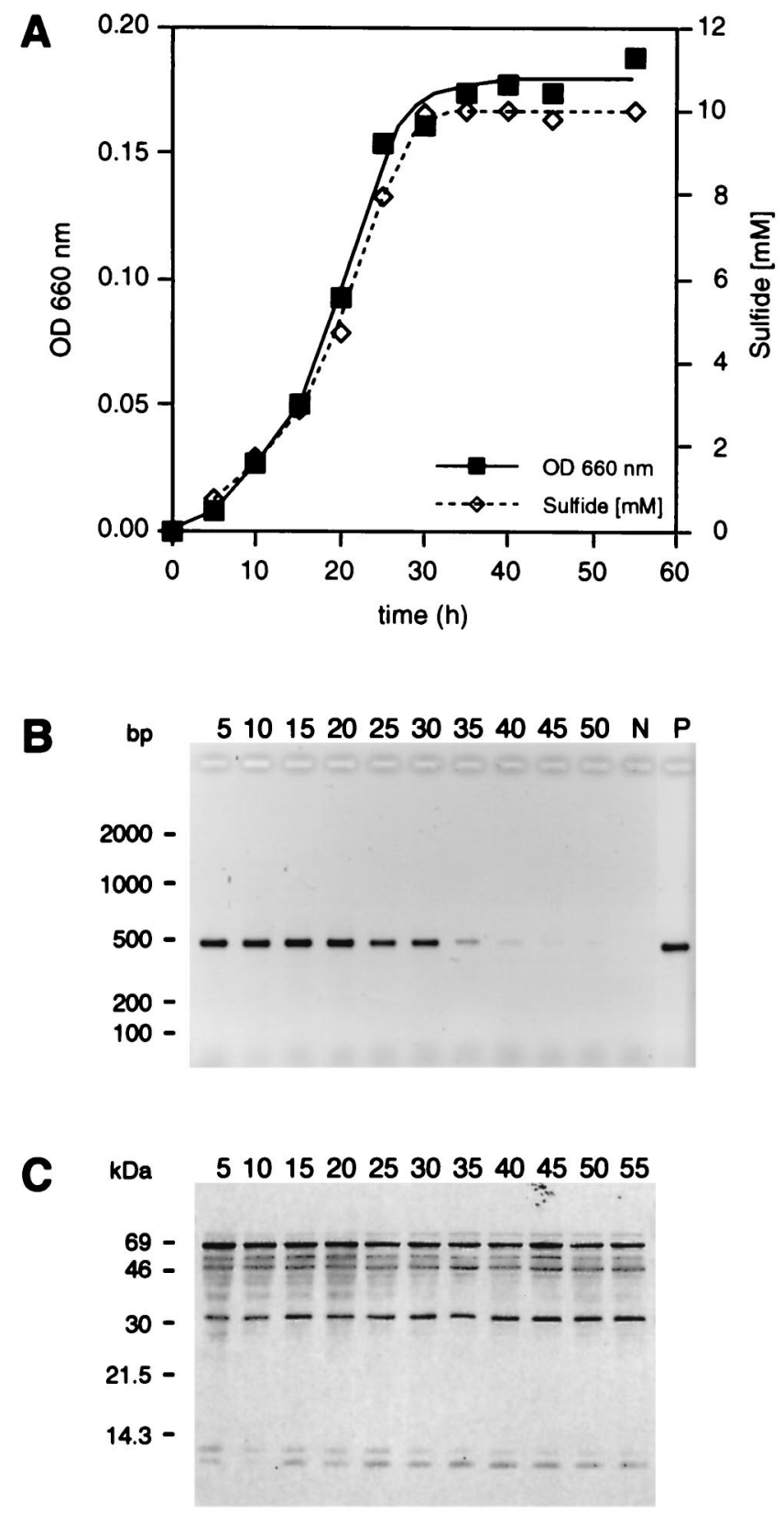

FIG. 1. Expression of the [NiFe] hydrogenase gene during growth of $D$. baculatus DSM 2555 on lactate. (A) Growth curve and sulfide production. OD, optical density. (B) Detection of [NiFe] hydrogenase mRNA by analysis of $5 \mu \mathrm{l}$ of RT-PCR products in a $2 \%$ (wt/vol) agarose gel. The cDNA synthesis was performed using $1 \mu \mathrm{g}$ of total RNA in a final volume of $20 \mu \mathrm{l} ; 1 \mu \mathrm{l}$ of the reaction mixture was amplified in a $50-\mu \mathrm{l} \mathrm{PCR}$. A negative image of an ethidium bromidestained gel is shown. The numbers above the lanes indicate the time of sampling in hours after inoculation. Lane N, negative control of the PCR, without DNA; lane P, positive control, using 20 ng DNA of D. baculatus DSM 2555. (C) Immunodetection of the [NiFe] hydrogenase in cell lysates after Western blotting. A 2- $\mu$ g sample of protein per lane was loaded onto the gel. Proteins of ca. 60 and $30 \mathrm{kDa}$ corresponding to the large and small subunits, respectively, of the [NiFe] hydrogenase were stained. The numbers above the lanes indicate the time of sampling in hours after inoculation. 

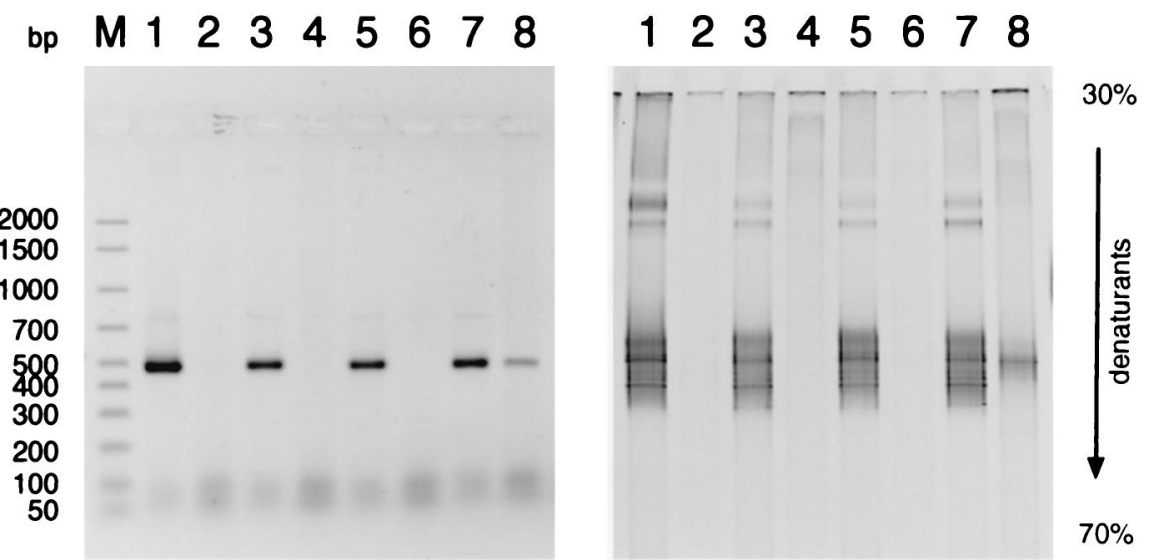

FIG. 2. Denitrifying bioreactor: analysis of PCR products obtained after amplification of DNA and RNA obtained from a sample taken directly out of the denitrifying bioreactor (lanes 1 and 2, respectively) and subsamples incubated in medium without substrate (lanes 3 and 4, respectively), with oxygen (lanes 5 and 6 , respectively), and with hydrogen (lanes 7 and 8, respectively). DNA amplification was performed with $0.5 \mu \mathrm{g}$ of DNA. The cDNA synthesis was performed with $1 \mu \mathrm{g}$ of total RNA in a final volume of $20 \mu \mathrm{l} ; 5 \mu \mathrm{l}$ of the reaction mixture was amplified in a PCR. PCR products from three 50- $\mu \mathrm{l}$ reaction mixtures were pooled, and the volume was reduced to $1 / 10$ by ethanol precipitation. (A) PCR products (1 1 l, corresponding to $10 \mu \mathrm{l}$ of the initial reaction mixture) separated in a $2 \%$ (wt/vol) agarose gel. Lane M, DNA size standard (Bio-Rad). (B) DGGE analysis of PCR products (10 $\mu$ l, corresponding to $100 \mu l$ of the initial reaction mixture). Negative images of ethidium bromide-stained gels are shown.

teria in lactate-sulfate and hydrogen-sulfate media were also examined. Amplified [NiFe] hydrogenase gene fragments and mRNA were detected in all tested samples. The DGGE analysis of the PCR products is shown in Fig. 3. The amplified gene fragments from a sample taken directly out of the bioreactor (original sample) and samples of the enrichment cultures harvested 1 day after inoculation produced three distinct bands (Fig. 3). The same electrophoresis pattern was observed for PCR products derived from the $[\mathrm{NiFe}] \mathrm{mRNA}$ in the original sample and in the enrichment with hydrogen. Conversely, mRNA amplificates from the lactate enrichment showed a weak but obviously different pattern. This pattern became more visible after analysis of PCR products obtained from nucleic acids of cultures that were incubated longer with lactate. Two additional DGGE bands appeared (Fig. 3), while other bands disappeared. The latter enrichment cultures showed an increased production of sulfide compared to cultures harvested earlier.

Genetic diversity of the [NiFe] hydrogenase of Desulfovibrio spp. The [NiFe] hydrogenase gene fragments defined by primers Hyd1F and Hyd5R of a variety of characterized Desulfovibrio strains were sequenced. On average, 360 nucleotides were determined. The aligned nucleotide sequences (not shown) as well as the deduced amino acid sequences (Fig. 4) were compared. The calculated distance-similarity matrix is given in Table 2. The sequences of most strains showed 70 to $75 \%$ similarity. Higher similarities were found only for strain DSM 644 and strain Miyazaki of the species D. vulgaris, with $87.5 \%$ similarity on the DNA level and $95.5 \%$ similarity for the deduced amino acid sequence. $D$. sulfodismutans and $D$. fructosovorans also showed high similarities of $85.9 \%$ on the DNA level and $84.8 \%$ for the deduced amino acid sequence.

Genetic diversity of the [NiFe] hydrogenase in anaerobic bioreactors. Sequence data were also obtained from PCR products of the bioreactor samples that were previously separated by DGGE. The DGGE pattern of amplified [NiFe] gene fragments obtained from samples of the denitrifying bioreactor exhibited five distinct bands (Fig. 2B). They were designated
K6S1, K6S2, K6S4, K6S8, and K6S6 (bands in electrophoresis direction from top to bottom). The PCR product derived from mRNA corresponds to K6S8. By sequencing the DNA fragments of several bands, it could be confirmed that PCR products with the same position in the denaturing gradient gels have identical nucleotide sequences.

The nucleotide and deduced amino acid sequences of K6S1, K6S2, K6S4, K6S8, and K6S6 were analyzed by comparative sequence analysis (Table 2). They showed high similarity val-

\section{3}

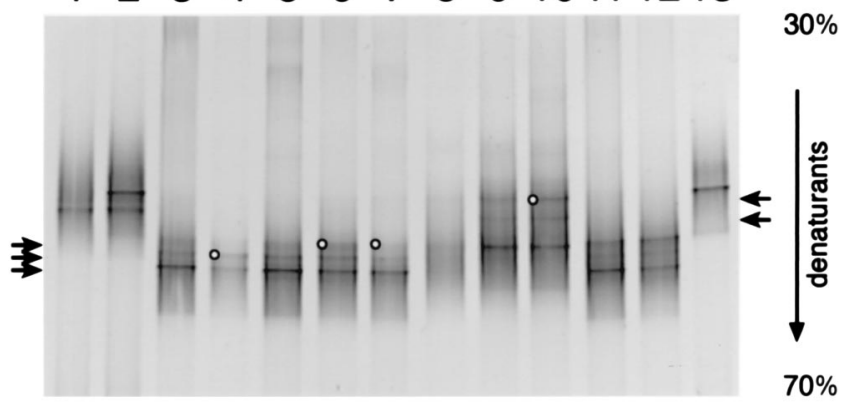

FIG. 3. Methanogenic bioreactor: DGGE analysis of PCR products obtained after amplification of DNA and RNA obtained from a sample taken directly out of the methanogenic bioreactor (lanes 3 and 4, respectively) and enrichment cultures incubated in medium without substrate (lanes 5 and 6 , respectively), with lactate (lanes 7 and 8 , respectively; lanes 9 and 10, respectively, after the first transfer of the culture in fresh lactate medium), and with hydrogen (lanes 11 and 12 , respectively). DNA amplification was performed with $0.1 \mu \mathrm{g}$ of DNA. The cDNA synthesis was performed with $1 \mu \mathrm{g}$ of total RNA in a final volume of 20 $\mu \mathrm{l} ; 5 \mu \mathrm{l}$ of the reaction mixture was amplified in a PCR. A 40- $\mu$ l volume of PCR products from the $50-\mu l$ reaction mixtures was loaded onto the gel. PCR products from DNA of $D$. gigas DSM 1382 (lane 1) and D. vulgaris DSM 644 (lane 13) and a mixture of the two PCR products (lane 2) were run as standards. A negative image of an ethidium bromide-stained gel is shown. Three distinct bands (arrows on the left) were produced from the original sample and the enrichment culture samples harvested 1 day after inoculation. After incubation with lactate, two additional bands appeared (arrows on the right). The small circles indicate gel portions that were excised for reamplification and sequencing. 
K6S1

K6S2

$\mathrm{K} 6 \mathrm{~S} 4$

$\mathrm{K} 6 \mathrm{~S} 8$

K6S6

$\mathrm{K} 5 \mathrm{~S} 18$

$\mathrm{K} 5 \mathrm{~S} 12 / 14$

K5S5

PIB2

D.baculatus DSM 2555

D.desulfuricans DSM 1924

D.desulfuricans DSM 1926

D.longus DSM 6739

D.sulfodismutans DSM 3696

D.vulgaris DSM 644

D.vulgaris DSM 1744

D.vulgaris Miyazaki

D.fructosovorans

D.gigas

E.coli

K6S1

K6S2

$\mathrm{K} 6 \mathrm{~S} 4$

K6S8

K6S6

K5S18

$\mathrm{K} 5 \mathrm{~S} 12 / 14$

K5S5

PIB2

D.baculatus DSM 2555

D.desulfuricans DSM 1924

D.desulfuricans DSM 1926

D.longus DSM 6739

D.sulfodismutans DSM 3696

D.vulgaris DSM 644

D.vulgaris DSM 1744

D.vulgaris Miyazaki

D.fructosovorans

D.gigas

E.coli
..........VCTYVHALASTRCVDNAVKV--NIPANARMMRNLVMGAQYLHDHIVHFYHLHALDWVDVTNALKADP

........RCGVCTYVHALASTRCVDNAVKV--N IPANARMMRNLVMGAQYLHDHIVHFYHLHALDWVDVTNALKADP

$\ldots \ldots \ldots . .$. VCTYVHALASTRCVDNAVKV--NIPVNARLMRNLVMGAQYLHDHIVHFYHLHALDWVDVTNALKADP

$\ldots \ldots \ldots . .$. VCTYVHALASTRCVDNAVKV--NIPANARMMRNLVMASQYLHDHIVHFYHLHALDWVDVTNALKADP

.......ACGVCTYVHALASTRCVDNAVKV--NIPANARMMRNLVMAAQYLHDHIVHFYHLHALDWVDVTNALKADP

........GGVCTYVHALASTRCVDNAVKV--NIPANARMMRNLVMAAQYLHDHIVHFYHLHALDWVDVTNALKADP

$\ldots \ldots \ldots \ldots$ CTYVHALASTRCVDNAVKV--NIPANARMMRNLVMAAQYLHDHIVHFYHLHALDWVDVTNALKADP

.......... CTYTHALASTRCVDNAVGVDKNLPDNARLIRNLVLAAQFLHDHIVHFYHLHALDWVDVTAALTADP

........ SCGVCTYVHALGSIRCVDNTVGVDKVLPHNAT I IRNLVLASQFMHDHIVHFYHLHALDFVNVANVLNADV

$\ldots \ldots \ldots . .$. VCTYTHALASTRCVDNAVGVDANLPDNARLIRNLVLAAQFLHDHIVHFYHLHALDWVDVTGALTADP

$\ldots \ldots \ldots . . .$. GVCTYTHALASTRALEDA IN--KP IPANATY IRNLVMAMQFMHDHVVHFYHLHALDFVDVANALQADP

.......... GVCTNVHALASVRCVDDAVGV--SIPENAT IFRNLVLAQQFLHDHIVHFYHLHALDWVDVVSGLSADP

$\ldots \ldots \ldots \ldots$ CTYTHALASTRCVDNAVGV--KIPKNATLIRNLVLAAQFMHDHIVHFYHLHALDWVNVANVLNADP

$\ldots \ldots \ldots$ GVCTYVHALASTRCVDNAVKV--NIPANARMMRNLVMAAQYLHDHIVHFYHLHALDWVDVTNALKADP

.......TCGVCTYTHALASTRCVDNAVGV--HIPKNATYIRNLVLGAQYLHDHIVHFYHLHALDFVDVTNALKADP

.........GVCTYVHALASVRSVDNAVGVDKVLPHNATI IRNLVVMAAQFMHDH IVHFYHLHALDFVDVAGCLSADV RDAQHFTQRTCGVCTYTHALASTRCVDNAVGV--HIPKNATYIRNLVLGAQYLHDHIVHFYHLHALDFVDVTAALKADP RDAQHFTQRACGVCTYVHALASSRCVDDAVKV--SIPANARMMRNLVMASQYLHDHLVHFYHLHALDWVDVTAALKADP RDAQHFTQRACGVCTYVHALASVRAVDNCVGV--KIPENATLMRNL TMGAQYMHDHLVHFYHLHALDWVNVANALNADP RDARAFVERICGVCTGVHALASVYAIEDAIGI--KVPDNANI IRNIMLATL WCHDHLVHFYQLAGMDWIDVLDALKADP

FIG. 4. Alignment of deduced amino acid sequences of [NiFe] hydrogenases obtained from two different experimental bioreactors and from characterized Desulfovibrio spp.

ues ranging from 88 to $97.6 \%$ on the DNA level; similarities of the deduced amino acid sequences were above $90 \%$. The highest similarity with sequences of characterized Desulfovibrio spp. was found for D. sulfodismutans. The sequence of K6S6 was almost identical to the sequence of that species and differed by only 1 amino acid (99.1\% similarity).

For the methanogenic bioreactor, sequences were obtained from PCR products of four different DGGE bands. The selected bands (Fig. 3) were designated as follows: K5S18 in lane 4, K5S14 in lane 6, K5S12 in lane 7, and K5S5 in lane 10. Bands K5S14 and K5S12 showed the same position within the denaturing gradient gel, and identical sequences (named K5S12/14) were determined for those DNA fragments.

The results of the comparative sequence analysis are presented in Table 2. K5S12/14 and K5S18 showed 91.7\% similarity with each other. A very low level of variation was ob- served by comparison with the sequences obtained from the denitrifying bioreactor and therefore also with the [NiFe] hydrogenase sequence of D. sulfodismutans. For K6S6 and $\mathrm{K} 5 \mathrm{~S} 12 / 14$, identical amino acid sequences were determined as well. However, K5S5, a sequence which was present exclusively in the lactate enrichment cultures, showed only $76.5 \%$ similarity to the nucleotide sequence of $D$. sulfodismutans but $87.7 \%$ similarity to D. baculatus DSM 2555 (Table 2).

Phylogenetic analysis. Evolutionary relationships were calculated from the nucleotide and amino acid sequences by using different algorithms, i.e., the distance method and parsimony. Although the constructed trees varied slightly depending on the algorithm and depending on whether DNA (Fig. 5A) or amino acid sequences (Fig. 5B) were used, some general features could be observed. As shown in Fig. 5, the sequences of D. vulgaris strains Miyazaki and DSM 644 always grouped 








FIG. 5. Evolutionary trees of [NiFe] hydrogenase sequences calculated by the distance matrix method from the nucleotide sequences (A) and the deduced amino acid sequences (B). The percentages of 100 bootstrap resamplings that support the branching pattern are indicated; the values were determined with parsimony (PAUP) (top values) and with the distance method (SEQBOOT) (bottom values).

together. The same was found for the sequences of $D$. vulgaris DSM 1744 and PIB2 ("D. oxyclinae") as well as for D. baculatus DSM 2555 and one of the sequences obtained from the methanogenic bioreactor, i.e., sequence K5S5. Sequences K5S12 and K5S18 and those obtained from the denitrifying bioreactor (K6 sequences) consistently formed a cluster with the sequences of $D$. sulfodismutans and $D$. fructosovorans. These groupings, determined with two different algorithms (parsimony and distance matrix), were validated by high bootstrap values for both nucleic acid and amino acid sequences (Fig. 5).

\section{DISCUSSION}

Expression of the [NiFe] hydrogenase gene in Desulfovibrio spp. We investigated the expression of the [NiFe] hydrogenase gene in pure cultures to determine if metabolically active strains, such as growing Desulfovibrio spp., can be identified by the detection of the $[\mathrm{NiFe}]$ hydrogenase mRNA. Hydrogen metabolism is a central bioenergetic pathway in Desulfovibrio spp. that involves hydrogen consumption and production under both sulfate-reducing and fermentative conditions (14). Different classes of hydrogenases, viz., [NiFe], [NiFeSe], and $[\mathrm{Fe}]$ hydrogenases, have been identified within the genus (10). Their genes are unevenly distributed among Desulfovibrio strains (54). The complexity of the hydrogen metabolism and the hydrogenase system in Desulfovibrio spp. makes it difficult to elucidate the physiological roles for the different hydrogenases. However, the [NiFe] hydrogenase gene is present in all Desulfovibrio strains tested so far (54). In Desulfovibrio spp. in which this is the only hydrogenase gene, the [NiFe] hydrogenase is responsible for all aspects of hydrogen metabolism (15, 31).

We tested various Desulfovibrio spp. containing different numbers of hydrogenase genes, including the following: $D$. vulgaris DSM 644, which possesses at least three different hydrogenase genes; $D$. desulfuricans DSM 1926, containing two hydrogenase genes; and $D$. gigas, which contains only the [NiFe] hydrogenase gene (54). Transcription of the [NiFe] hydrogenase gene was demonstrated in all strains growing in hydrogensulfate and lactate-sulfate media.

In addition, experiments performed to monitor [NiFe] hydrogenase expression during growth on lactate showed a decrease in $[\mathrm{NiFe}]$ hydrogenase mRNA content until no amplified mRNA sequences were visible when the cultures reached the stationary phase. The same expression pattern has been observed by using Northern blotting for the [Fe] hydrogenase of $D$. vulgaris growing with organic substrates; the decrease of the mRNA was accompanied by a decrease in hydrogenase activity (52). In contrast to the mRNA, we found that the amount of the $[\mathrm{NiFe}]$ hydrogenase protein remained constant during growth. This might indicate a very stable protein. Studies with $D$. vulgaris showed that even in aged cultures contain- 
ing nonviable cells, the hydrogenases could be reactivated by addition of the reducing agent dithionite (4).

We did not measure the hydrogenase activity, since the enzyme assays reflect the total hydrogenase activity and not the activities of the different types of hydrogenases. It has been shown by others that the extent of [NiFe] hydrogenase activity can vary in different Desulfovibrio spp. from less than $5 \%$ of the total hydrogenase activity, as demonstrated for $D$. vulgaris by expression of antisense mRNA (51), to $90 \%$ of the total, as shown by marker exchange mutagenesis in $D$. fructosovorans (42). Furthermore, it has been previously demonstrated that the total hydrogenase activity is correlated with bacterial growth $(31,51,52)$.

In summary, our results indicate that the transcription of the [NiFe] hydrogenase gene is correlated with bacterial growth and therefore with the metabolic activity, i.e., sulfate reduction rate, in various Desulfovibrio spp. Thus, the detection of the [NiFe] hydrogenase mRNA appears to be a suitable tool with which to determine metabolically active populations in environmental samples.

Presence and expression of [NiFe] hydrogenase genes in anaerobic bioreactors. We were able to amplify [NiFe] hydrogenase gene fragments from samples of the denitrifying bioreactor as well as from subsamples incubated with $\mathrm{H}_{2}$ and $\mathrm{O}_{2}$. Different bands obtained after DGGE analysis of the PCR products suggest the presence of as many Desulfovibrio strains in these samples. Identical electrophoresis patterns for all tested DNA samples indicate that the composition of the Desulfovibrio population was constant over $20 \mathrm{~h}$ after addition of $\mathrm{H}_{2}$ or $\mathrm{O}_{2}$. However, from the DGGE analysis of PCR products derived from mRNA and their positions in the gel, we conclude that only one strain within the Desulfovibrio population actively transcribed the [NiFe] hydrogenase gene after incubation with $\mathrm{H}_{2}$.

The presence of different Desulfovibrio spp. within the bacterial community of the methanogenic bioreactor was also shown. In contrast to the strains from the denitrifying bioreactor, all detected Desulfovibrio strains actively transcribed the [NiFe] hydrogenase gene, as demonstrated after DGGE analysis of PCR products derived from DNA and RNA. However, the electrophoresis pattern of the original bioreactor sample differed from the pattern of subsamples that were incubated in lactate-sulfate medium. This indicates that the composition of the Desulfovibrio population had changed during enrichment with lactate. The change of the population and thus the changing environmental conditions could already be observed after 1 day of incubation with lactate, since those samples showed different patterns for amplified gene fragments and mRNA.

Genetic diversity and identity of Desulfovibrio spp. in anaerobic bioreactors. Determination of the genetic relationship and identification of bacteria based on DNA sequences are possible only if enough sequence data are available. Only three $[\mathrm{NiFe}]$ hydrogenase sequences, viz., those of $D$. vulgaris $(8), D$. fructosovorans $(41)$, and D. gigas $(24,53)$, were available from the EMBL nucleotide database. Thus, $[\mathrm{NiFe}]$ hydrogenase gene fragments from a variety of characterized Desulfovibrio spp. were sequenced to create a framework for the identification of uncultivated Desulfovibrio strains by comparative sequence analysis.

In accordance with the results of $\mathrm{Wu}$ and Mandrand (59), who examined the sequences of 30 microbial hydrogenases of various bacterial groups, the [NiFe] hydrogenases of Desulfovibrio spp. form a distinct cluster of related sequences. However, our comparison of partial gene sequences of 16 strains and of the three previously published sequences revealed a great genetic diversity. One branch containing deep lineages of Desulfovibrio spp. was also observed in phylogenetic trees based on $16 \mathrm{~S}$ rRNA sequences (9). While the [NiFe] hydrogenase sequences of two strains belonging to the species $D$. vulgaris showed a high percent similarity and formed an evolutionarily related group, which was supported by high bootstrap values, different strains of $D$. desulfuricans did not. Devereux et al. (9) also found that on the basis of 16S rRNA sequences, some strains of $D$. desulfuricans were not closely related. They concluded that those strains are misclassified. Thus, the relationship of [NiFe] hydrogenase sequences is largely consistent with the relationship of Desulfovibrio spp. derived from 16S rRNA sequences (9).

[NiFe] hydrogenase sequences obtained from the PCR products of the denitrifying bioreactor showed very high similarities to each other. Such closely related sequences could be due to multiple copies of the gene in one organism. However, there is no evidence for such an organization of [NiFe] hydrogenase operons. Our results indicate the coexistence of closely related strains within the denitrifying bioreactor. On the basis of comparative sequence analysis, they are closely related to the species $D$. sulfodismutans. The type strain of this species was isolated from freshwater mud (2). D. sulfodismutans is characterized by the ability to conserve energy for growth under anaerobic conditions by disproportionation of thiosulfate or sulfite to sulfate and sulfide. Growth by sulfate reduction is slower than by disproportionation. The species also differs from the classical Desulfovibrio spp. by its inability to utilize pyruvate and its very slow growth on hydrogen. Interestingly, the $[\mathrm{NiFe}]$ hydrogenase sequence corresponding to the Desulfovibrio strain which actively transcribed the gene after incubation with $\mathrm{H}_{2}$ (K6S8) showed a high similarity to the sequence of D. sulfodismutans (95.5\% for the deduced amino acids). However, K6S8 also showed a high similarity (86.9\%) to the sequence of $D$. fructosovorans. $D$. fructosovorans, isolated from an estuarine sediment, is a typical $\mathrm{H}_{2}$ oxidizer, further characterized by its ability to utilize fructose (33).

Since the main metabolic process occurring in the denitrifying bioreactor concerns the conversion of nitrate to dinitrogen gas, it is not surprising that sulfate-reducing bacteria were presumably not active in a sample taken directly from the reactor. Besides, it is well known that nitrate inhibits sulfate reduction $(17,44)$, and it has been shown that sulfate reduction takes place within the denitrifying bioreactor when nitrate is exhausted (28). On the other hand, several Desulfovibrio spp. can reduce nitrate or nitrite to ammonia $(7,20,44)$. However, the closest relatives to the detected strains, $D$. sulfodismutans and $D$. fructosovorans, were unable to reduce nitrate $(2,33)$. According to Dalsgaard and Bak (7), the ability to reduce nitrate might be underestimated for sulfate-reducing bacteria because medium containing more than $0.1 \mathrm{mM}$ sulfide inhibits nitrate reduction. However, sulfide concentrations of more than $2 \mathrm{mM}$ were measured in the influent of the denitrifying bioreactor (28), and thus it is unlikely that the Desulfovibrio populations were directly involved in nitrogen metabolism.

In contrast, within methanogenic bioreactors sulfate-reducing bacteria and methanogenic archaea usually live in close association (34). The wastewater of the baker's yeast production plant contains high concentrations of sulfate, which is partly converted to sulfide in the methanogenic reactor (28). Hence, it is not surprising that the Desulfovibrio spp. present in a sample taken directly from a methanogenic bioreactor were actively transcribing the $[\mathrm{NiFe}]$ hydrogenase gene. Members of the detected population were also identified as D. sulfodismutans on the basis of their partial [NiFe] hydrogenase sequences. An additional hint that those strains were indeed similar to D. sulfodismutans arises from the inability to enrich 
them by using lactate-sulfate medium. Within the enrichments, strains containing [NiFe] hydrogenase sequences similar to that of $D$. baculatus DSM 2555 were found. DSM 2555 was isolated from an anaerobic intertidal sediment of the EmsDollard estuary on the border between The Netherlands and Germany (22). Our results present another example demonstrating the limitation of culture-dependent approaches to describing the structure of microbial communities.

In summary, closely related strains probably belonging to the species $D$. sulfodismutans were found in the denitrifying bioreactor as well as in the methanogenic bioreactor, where they were metabolically active. The coexistence of closely related bacterial strains in environmental samples was also suggested by Ueda et al. (49) in a study of $\mathrm{N}_{2}$-fixing bacteria. They obtained nifD sequences from the rice rhizosphere and found a low level of genetic diversity within sequence clusters. The same was also demonstrated by $\mathrm{Xu}$ and Tabita (61) for the $r b c L$ gene of $\mathrm{CO}_{2}$-fixing phytoplanktonic organisms in Lake Erie.

The concept of mRNA detection for the study of microbial activity. The detection of mRNA is a promising tool for monitoring the activity of microbes in the environment. The idea of this approach is that the abundance of a transcript may be related to the state of microbial activity. Such molecular approaches might serve to resolve microbial processes at the levels of specific populations, species, or even strains, whereas traditional methods, for example, radiotracer techniques, reflect microbial activity only at the community level. Northern blotting and mRNA probing as well as RT-PCR have been applied for this purpose $(37,60,61)$. In consideration of the main problems arising in studies of gene expression in the environment, Pichard and Paul (38) developed the concept of gene expression per gene dose. In order to account for changes in activity caused by increased transcription or changes in relative gene abundance caused, for example, by changes in cell population size, they suggested a hybridization approach to determine the levels of both specific mRNA and DNA.

Accordingly, we also used RNA as well as DNA as starting material for PCR amplification of [NiFe] hydrogenase gene nucleotide sequences. After DGGE analysis of the PCR products, we could distinguish the Desulfovibrio strains that expressed the gene, which we regarded as metabolically active, from the inactive strains. However, a disadvantage of a PCRbased method concerns the quantitation of transcript and gene abundances. Although quantitative PCR has been applied in the environmental context (36), a cautious use of PCR for quantitative purposes is indicated. Preferential amplification has been described, and factors determining the efficiency of PCR in complex DNA mixtures, as are common in the environment, are less well understood (46). Thus, we did not quantify the mRNA or target DNA in environmental samples explicitly and interpreted our results only in a semiquantitative way. Assuming a constant PCR bias for a specific sequence, the appearance and disappearance of a DGGE band should reflect the increase or decrease of the corresponding mRNA or gene(s).

In defining the function of sulfate-reducing bacteria in natural populations, it would be interesting to study in addition to the $[\mathrm{NiFe}]$ hydrogenase gene the expression of genes directly involved in sulfate reduction. Recently, a PCR assay for the dissimilatory sulfite reductase of sulfate-reducing bacteria was described (18). Transcripts of the gene encoding this enzyme could indicate organisms performing sulfate reduction, whereas transcripts of the [NiFe] hydrogenase gene probably indicate a general metabolic activity.

Examination of the presence and expression of genes in parallel, as described in this paper, is well suited to investigation of the dynamics of bacterial populations in the environment and their response to changing conditions. In addition to the application of more-classical approaches in microbial ecology, such as the use of radiotracer techniques and microelectrodes and the isolation of bacteria, the molecular approach will enable a better understanding of the structure and function of microbial communities.

\section{ACKNOWLEDGMENTS}

We thank Kirsten Habicht for providing us with cultures of $D$. sulfodismutans, Andreas Teske for providing DNA of isolate PIB2, and E. C. Hatchikian for the $[\mathrm{NiFe}]$ hydrogenase antibodies. We thank Tim Ferdelman for correcting the English and three anonymous reviewers for their remarks, which improved the manuscript.

This work was supported by the Max-Planck Society, Munich, Germany.

\section{REFERENCES}

1. Amann, R. I., W. Ludwig, and K.-H. Schleifer. 1995. Phylogenetic identification and in situ detection of individual microbial cells without cultivation. Microbiol. Rev. 59:143-169.

2. Bak, F., and N. Pfennig. 1987. Chemolithotrophic growth of Desulfovibrio sulfodismutans sp. nov. by disproportionation of inorganic sulfur compounds. Arch. Microbiol. 147:184-189.

3. Bradford, M. M. 1976. A rapid and sensitive method for the quantitation of microgram quantities of protein utilizing the principle of protein-dye binding. Anal. Biochem. 72:248-254.

4. Chatelus, C., P. Carrier, P. Saignes, M. F. Libert, Y. Berlier, P. A. Lespinat, G. Fauque, and J. LeGall. 1987. Hydrogenase activity in aged, nonviable Desulfovibrio vulgaris cultures and its significance in anaerobic biocorrosion. Appl. Environ. Microbiol. 53:1708-1710.

5. Cline, J. D. 1969. Spectrophotometric determination of hydrogen sulfide in natural waters. Limnol. Oceanogr. 14:454-458.

6. Cord-Ruwisch, R. 1985. A quick method for the determination of dissolved and precipitated sulfides in cultures of sulfate-reducing bacteria. J. Microbiol. Methods 4:33-36.

7. Dalsgaard, T., and F. Bak. 1994. Nitrate reduction in a sulfate-reducing bacterium, Desulfovibrio desulfuricans, isolated from rice paddy soil: sulfide inhibition, kinetics, and regulation. Appl. Environ. Microbiol. 60:291-297.

8. Deckers, H. M., F. R. Wilson, and G. Voordouw. 1990. Cloning and sequencing of a $[\mathrm{NiFe}]$ hydrogenase operon from Desulfovibrio vulgaris Miyazaki F. J. Gen. Microbiol. 136:2021-2028.

9. Devereux, R., S.-H. He, C. Doyle, S. Orkland, D. A. Stahl, J. LeGall, and W. B. Whitman. 1990. Diversity and origin of Desulfovibrio species: phylogenetic definition of a family. J. Bacteriol. 172:3609-3619.

10. Fauque, G., H. D. Peck, Jr., J. J. G. Moura, B. H. Huynh, Y. Berlier, D. V. DerVartanian, M. Teixeira, A. E. Przybyla, P. A. Lespinat, I. Moura, and J. LeGall. 1988. The three classes of hydrogenases from sulfate-reducing bacteria of the genus Desulfovibrio. FEMS Microbiol. Rev. 54:299-344.

11. Felsenstein, J. 1993. PHYLIP (Phylogeny Inference Package) version 3.5c. Department of Genetics, University of Washington, Seattle.

12. Felske, A., B. Engelen, U. Nübel, and H. Backhaus. 1996. Direct ribosome isolation from soil to extract bacterial rRNA for community analysis. Appl. Environ. Microbiol. 62:4162-4167.

13. Gilbert, D. G. 1992. SeqApp — a bio-sequence analysis application. Indiana University, Bloomington.

14. Hatchikian, E. C., V. M. Fernandez, and R. Cammack. 1990. The hydrogenases of sulfate-reducing bacteria: physiological, biochemical and catalytic aspects, p. 53-73. In J.-P. Belaich, M. Bruschi, and J.-L. Garcia (ed.), Microbiology and biochemistry of strict anaerobes involved in interspecies hydrogen transfer. Plenum Press, New York, N.Y.

15. Hatchikian, E. C., N. Forget, A. Bernadac, D. Alazard, and B. Ollivier. 1995 Involvement of a single periplasmic hydrogenase for both hydrogen uptake and production in some Desulfovibrio species. Res. Microbiol. 146:129-141.

16. Jeffrey, W. H., S. Nazareth, and T. Barkay. 1996. Detection of the merA gene and its expression in the environment. Microb. Ecol. 32:293-303.

17. Jennemann, G. E., M. J. McInerney, and R. M. Knapp. 1986. Effect of nitrate on biogenic sulfide production. Appl. Environ. Microbiol. 51:12051211.

18. Karkhoff-Schweizer, R. R., D. P. W. Huber, and G. Voordouw. 1995. Conservation of the genes for the dissimilatory sulfite reductase from Desulfovibrio vulgaris and Archaeoglobus fulgidus allows their detection by PCR. Appl. Environ. Microbiol. 61:290-296.

19. Klüber, H. D., S. Lechner, and R. Conrad. 1995. Characterization of populations of aerobic hydrogen-oxidizing soil bacteria. FEMS Microbiol. Ecol. 16:167-176.

20. Krekeler, D., and H. Cypionka. 1995. The preferred electron acceptor of 
Desulfovibrio desulfuricans CSN. FEMS Microbiol. Ecol. 17:271-278.

21. Krekeler, D., P. Sigalevich, A. Teske, H. Cypionka, and Y. Cohen. 1997. A sulfate-reducing bacterium from the oxic layer of a microbial mat from Solar Lake (Sinai), Desulfovibrio oxyclinae sp. nov. Arch. Microbiol. 167:369-375.

22. Laanbroek, H. J., and H. J. Geerligs. 1983. Influence of clay particles (illite) on substrate utilization by sulfate-reducing bacteria. Arch. Microbiol. 134: 161-163.

23. Laemmli, U. K. 1970. Cleavage of structural proteins during the assembly of the head of bacteriophage T4. Nature 227:680-685.

24. Li, C., H. D. Peck, Jr., J. LeGall, and A. E. Przybyla. 1987. Cloning, characterization, and sequencing of the genes encoding the large and small subunits of the periplasmic [NiFe] hydrogenase of Desulfovibrio gigas. DNA 6:539-551.

25. Lovell, C. R., and Y. Hui. 1991. Design and testing of a functional groupspecific DNA probe for the study of natural populations of acetogenic bacteria. Appl. Environ. Microbiol. 57:2602-2609.

26. Marck, C. 1988. 'DNA Strider': a 'C' program for fast analysis of DNA and protein sequences on the Apple Macintosh family of computers. Nucleic Acids Res. 16:1829-1836.

27. McDonald, I. R., E. M. Kenna, and J. C. Murrell. 1995. Detection of methanotrophic bacteria in environmental samples with the PCR. Appl. Environ. Microbiol. 61:116-121.

28. Mulder, A., A. A. van de Graaf, L. A. Robertson, and J. G. Kuenen. 1995. Anaerobic ammonium oxidation discovered in a denitrifying fluidized bed reactor. FEMS Microbiol. Ecol. 16:177-184.

29. Muyzer, G., and N. B. Ramsing. 1995. Molecular methods to study the organization of microbial communities. Water Sci. Technol. 32:1-9.

30. Muyzer, G., S. Hottenträger, A. Teske, and C. Wawer. 1996. Denaturing gradient gel electrophoresis of PCR-amplified 16S rDNA - a new molecular approach to analyse the genetic diversity of mixed microbial communities, $\mathrm{p}$. 3.4.4.1-3.4.4.22. In A. D. L. Akkermans, J. D. van Elsas, and F. J. de Bruijn (ed.), Molecular microbial ecology manual, 2nd ed. Kluwer Academic Publishers, Dordrecht, The Netherlands.

31. Niviere, V., A. Bernadac, N. Forget, V. M. Fernandez, and E. C. Hatchikian. 1991. Localization of hydrogenase in Desulfovibrio gigas cells. Arch. Microbiol. 155:579-586.

32. Oelmüller, U., N. Krüger, A. Steinbüchel, and G. C. Friedrich. 1990. Isolation of prokaryotic RNA and detection of specific mRNA with biotinylated probes. J. Microbiol. Methods 11:73-84.

33. Ollivier, B., R. Cord-Ruwisch, E. C. Hatchikian, and J. L. Garcia. 1988. Characterization of Desulfovibrio fructosovorans sp. nov. Arch. Microbiol. 149:447-450.

34. Oude Elferink, S. J. W. H., A. Visser, L. W. Hulshoff Pol, and A. J. M. Stams. 1994. Sulfate reduction in methanogenic bioreactors. FEMS Microbiol. Rev. 15:119-136.

35. Paul, J. H. 1996. Carbon cycling: molecular regulation of photosynthetic carbon fixation. Microb. Ecol. 32:231-245.

36. Picard, C., C. Ponsonnet, E. Paget, X. Nesme, and P. Simonet. 1992. Detection and enumeration of bacteria in soil by direct DNA extraction and polymerase chain reaction. Appl. Environ. Microbiol. 58:2717-2722.

37. Pichard, S. L., and J. H. Paul. 1991. Detection of gene expression in genetically engineered microorganisms and natural phytoplankton populations in the marine environment by mRNA analysis. Appl. Environ. Microbiol. 57: 1721-1727.

38. Pichard, S. L., and J. H. Paul. 1993. Gene expression per gene dose, a specific measure of gene expression in aquatic microorganisms. Appl. Environ. Microbiol. 59:451-457.

39. Pichard, S. L., L. Campbell, J. B. Kang, F. R. Tabita, and J. H. Paul. 1996. Regulation of ribulose bisphosphate carboxylase gene expression in natural phytoplankton communities. I. Diel rhythms. Mar. Ecol. Prog. Ser. 139:257265.

40. Poulsen, L. K., G. Ballard, and D. A. Stahl. 1993. Use of rRNA fluorescence in situ hybridization for measuring the activity of single cells in young and established biofilms. Appl. Environ. Microbiol. 59:1354-1360.

41. Rousset, M., Z. Dermoun, C. E. Hatchikian, and J. P. Belaich. 1990. Cloning and sequencing of the locus encoding the large and small subunit genes of the periplasmic $[\mathrm{NiFe}]$ hydrogenase of Desulfovibrio fructosovorans. Gene 94:95-101.

42. Rousset, M., Z. Dermoun, M. Chippaux, and J. P. Belaich. 1991. Marker exchange mutagenesis of the hydN genes in Desulfovibrio fructosovorans. Mol. Microbiol. 5:1735-1740.

43. Sambrook, J., E. F. Fritsch, and T. Maniatis. 1989. Molecular cloning: a laboratory manual, 2nd ed. Cold Spring Harbor Laboratory, Cold Spring Harbor, N.Y.

44. Seitz, H.-J., and H. Cypionka. 1986. Chemolithotrophic growth of Desulfovibrio desulfuricans with hydrogen coupled to ammonification of nitrate and nitrite. Arch. Microbiol. 146:63-67.

45. Sinigalliano, C. D., D. N. Kuhn, and R. D. Jones. 1995. Amplification of amoA gene from diverse species of ammonium-oxidizing bacteria and from an indigenous bacterial population from seawater. Appl. Environ. Microbiol. 61:2702-2706.

46. Suzuki, M. T., and S. J. Giovannoni. 1996. Bias caused by template annealing in the amplification of mixtures of $16 \mathrm{~S}$ rRNA genes by PCR. Appl. Environ. Microbiol. 62:625-630.

47. Swofford, D. L. 1991. PAUP: phylogenetic analysis using parsimony. Illinois Natural History Survey, Champaign.

48. Teske, A., C. Wawer, G. Muyzer, and N. B. Ramsing. 1996. Distribution of sulfate-reducing bacteria in a stratified fjord (Mariager Fjord, Denmark) as evaluated by most-probable-number counts and denaturing gradient gel electrophoresis of PCR-amplified ribosomal DNA fragments. Appl. Environ. Microbiol. 62:1405-1415.

49. Ueda, T., Y. Suga, N. Yahiro, and T. Matsuguchi. 1995. Genetic diversity of $\mathrm{N}_{2}$-fixing bacteria associated with rice roots by molecular evolutionary analysis of a nifD library. Can. J. Microbiol. 41:235-240.

50. Van de Graaf, A. A., P. de Bruijn, L. A. Robertson, M. S. M. Jetten, and J. G. Kuenen. 1996. Autotrophic growth of anaerobic, ammonium-oxidising microorganisms in a fluidized bed reactor. Microbiology (UK) 142:2187-2196.

51. Van den Berg, W. A. M., W. M. A. M. van Dongen, and C. Veeger. 1991. Reduction of the amount of periplasmic hydrogenase in Desulfovibrio vulgaris (Hildenborough) with antisense RNA: direct evidence for an important role of this hydrogenase in lactate metabolism. J. Bacteriol. 173:3688-3694.

52. Van den Berg, W. A. M., J. P. W. G. Stokkermans, and W. M. A. M. van Dongen. 1993. The operon for the Fe-hydrogenase in Desulfovibrio vulgaris (Hildenborough): mapping of the transcript and regulation of expression. FEMS Microbiol. Lett. 110:85-90.

53. Voordouw, G., N. K. Menon, J. LeGall, E.-S. Choi, H. D. Peck, Jr., and A. E. Przybyla. 1989. Analysis and comparison of nucleotide sequences encoding the genes for [NiFe] and [NiFeSe] hydrogenase from Desulfovibrio gigas and Desulfovibrio baculatus. J. Bacteriol. 171:2894-2899.

54. Voordouw, G., V. Niviere, F. G. Ferris, P. M. Fedorak, and D. W. S. Westlake. 1990. Distribution of hydrogenase genes in Desulfovibrio spp. and their use in identification of species from the oil field environment. Appl. Environ. Microbiol. 56:3748-3754.

55. Ward, B. B. 1996. Nitrification and denitrification: probing the nitrogen cycle in aquatic environments. Microb. Ecol. 32:247-261.

56. Wawer, C., and G. Muyzer. 1995. Genetic diversity of Desulfovibrio spp. in environmental samples analyzed by denaturing gradient gel electrophoresis of [NiFe] hydrogenase gene fragments. Appl. Environ. Microbiol. 61:22032210.

57. Widdel, F. 1988. Microbiology and ecology of sulfate- and sulfur-reducing bacteria, p. 469-585. In A. J. B. Zehnder (ed.), Biology of anaerobic microorganisms. John Wiley \& Sons, New York, N.Y.

58. Widdel, F., and F. Bak. 1992. Gram-negative mesophilic sulfate-reducing bacteria, p. 3352-3378. In A. Balows, H. G. Trüper, M. Dworkin, W. Harder, and K. H. Schleifer (ed.), The prokaryotes, 2nd ed., vol. IV. Springer Verlag, New York, N.Y.

59. Wu, L.-F., and M. A. Mandrand. 1993. Microbial hydrogenases: primary structure, classification, signatures and phylogeny. FEMS Microbiol. Rev. 104:243-270.

60. Wyman, M., J. P. Zehr, and D. G. Capone. 1996. Temporal variability in nitrogenase gene expression in natural populations of the marine cyanobacterium Trichodesmium thiebautii. Appl. Environ. Microbiol. 62:1073-1075.

61. Xu, H. H., and F. R. Tabita. 1996. Ribulose-1,5-bisphosphate carboxylase/ oxygenase gene expression and diversity of Lake Erie planktonic microorganisms. Appl. Environ. Microbiol. 62:1913-1921.

62. Zehr, J. P., and D. G. Capone. 1996. Problems and promises of assaying the genetic potential for nitrogen fixation in the marine environment. Microb. Ecol. 32:263-281. 